\title{
Innovatief onderwijs ontwerpen in het gezondheidsdomein
}

Citation for published version (APA):

Merriënboer, J. J. G. (2010). Innovatief onderwijs ontwerpen in het gezondheidsdomein. Maastricht University. https://doi.org/10.26481/spe.20100604jm

Document status and date:

Published: 04/06/2010

DOI:

10.26481/spe.20100604jm

Document Version:

Publisher's PDF, also known as Version of record

\section{Please check the document version of this publication:}

- A submitted manuscript is the version of the article upon submission and before peer-review. There can be important differences between the submitted version and the official published version of record.

People interested in the research are advised to contact the author for the final version of the publication, or visit the DOI to the publisher's website.

- The final author version and the galley proof are versions of the publication after peer review.

- The final published version features the final layout of the paper including the volume, issue and page numbers.

Link to publication

\footnotetext{
General rights rights.

- You may freely distribute the URL identifying the publication in the public portal. please follow below link for the End User Agreement:

www.umlib.nl/taverne-license

Take down policy

If you believe that this document breaches copyright please contact us at:

repository@maastrichtuniversity.nl

providing details and we will investigate your claim.
}

Copyright and moral rights for the publications made accessible in the public portal are retained by the authors and/or other copyright owners and it is a condition of accessing publications that users recognise and abide by the legal requirements associated with these

- Users may download and print one copy of any publication from the public portal for the purpose of private study or research.

- You may not further distribute the material or use it for any profit-making activity or commercial gain

If the publication is distributed under the terms of Article $25 \mathrm{fa}$ of the Dutch Copyright Act, indicated by the "Taverne" license above, 


\section{Maastricht University}

\section{Prof. dr. Jeroen J. G. van Merriënboer}

Faculty of Health, Medicine and Life Sciences

Innovatief Onderwijs Ontwerpen in het Gezondheidsdomein

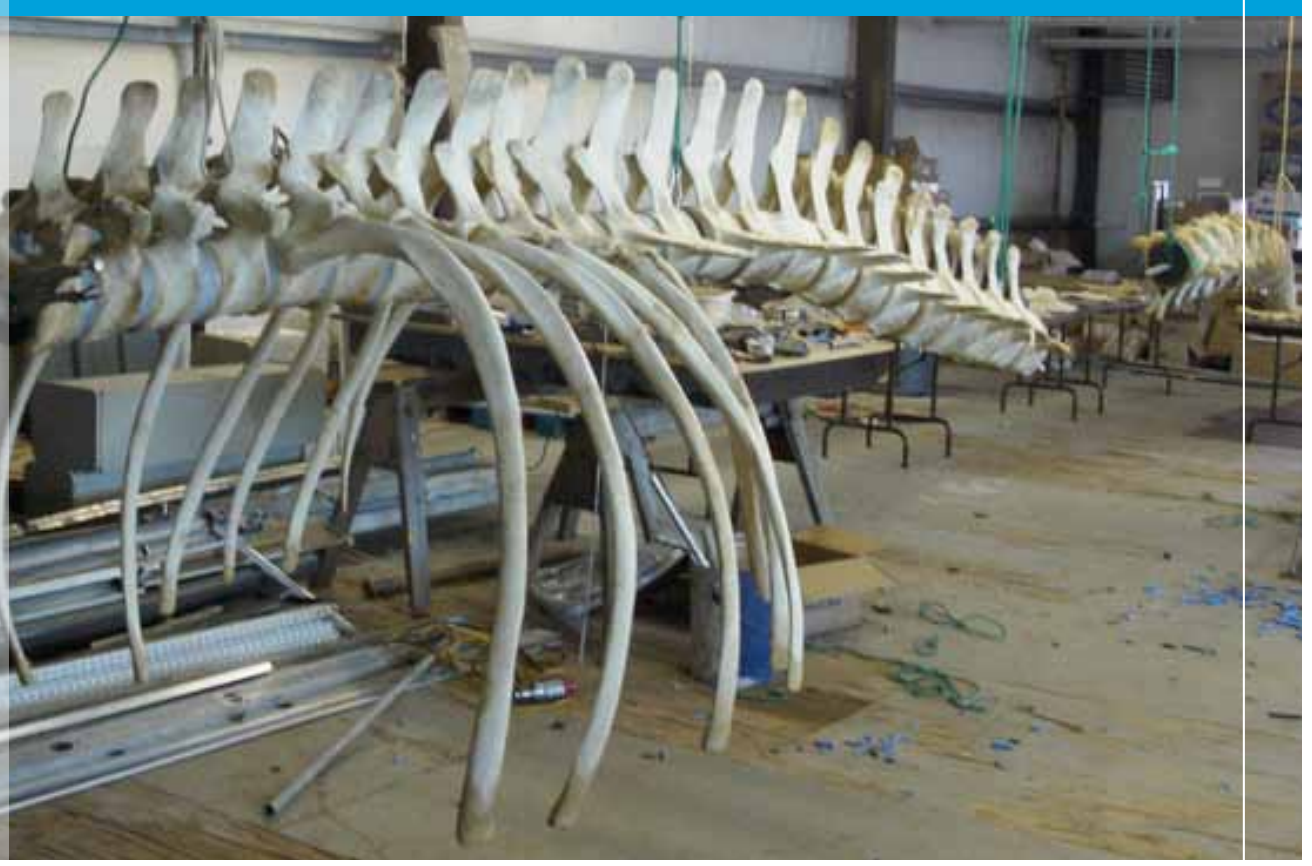


Innovatief Onderwijs Ontwerpen in het Gezondheidsdomein 


\section{Colofon}

Ontwerp en print: Océ Business Services, Maastricht

ISBN: 978-90-5681-333-8

Nur: 841

Alle rechten voorbehouden. Niets uit deze uitgave mag worden verveelvoudigd, opgeslagen in een geautomatiseerd gegevensbestand of openbaar gemaakt worden, zonder voorafgaande schriftelijke toestemming van de auteur of uitgever. 


\section{Innovatief Onderwijs Ontwerpen in het Gezondheidsdomein}

Mijnheer de Rector Magnificus, geacht College van Bestuur, geachte Decaan, geachte Raad van Bestuur, beste collega's, familie, vrienden en overige toehoorders. Ik ben verheugd vandaag deze inaugurele rede voor $u$ allen te mogen uitspreken.

Maastricht, 4 juni 2010

Prof. dr. Jeroen J. G. van Merriënboer 


\section{Inleiding}

De medische onderwijskunde bestudeert en analyseert onderwijs en leerprocessen in het gezondheidsdomein en gebruikt de verworven wetenschappelijke kennis om onderwijsvraagstukken op te lossen. In het gezondheidsdomein werken heel veel mensen met de ambitie om iedereen zo lang mogelijk gezond te houden en zieken zo snel mogelijk beter te maken. Het gaat daarbij om zeer uiteenlopende beroepen zoals artsen, apothekers, dierenartsen, diëtisten, fysiotherapeuten, gezondheidswetenschappers, laboranten, psychotherapeuten, tandartsen, verloskundigen en verpleegkundigen. Voor professionals in al deze beroepen geldt dat zij worden geconfronteerd met zeer snelle technologische en maatschappelijke veranderingen. Nieuwe medicijnen, nieuwe beeldvormende technieken en nieuwe behandelwijzen vragen om constante scholing en professionalisering. De zorg zelf verandert ook van karakter doordat steeds meer patiënten als gevolg van de vergrijzing boven de $65 \mathrm{zijn}$. Mede ten gevolge van deze vergrijzing is het aantal vacatures in de zorg groot en zal de komende jaren alleen maar toenemen. Het is dus belangrijk om (aankomend) professionals in het gezondheidsdomein optimaal op te leiden en voor te bereiden op een leven lang leren. In deze rede beantwoord ik de vraag hoe dat het beste bereikt kan worden.

De opbouw van mijn rede is als volgt. In de tweede paragraaf karakteriseer ik het gezondheidsdomein: Een complex en snel veranderend domein waarin zowel vakinhoudelijke als generieke competenties een belangrijke rol spelen. In de derde en vierde paragraaf beantwoord ik twee samenhangende vragen: (a) Hoe ontwerp je effectief en aantrekkelijk onderwijs voor dit domein en (b) hoe ziet zulk onderwijs er uit? Eerst zal ik betogen dat een holistische ontwerpaanpak vereist is: Zo'n aanpak start vanuit een analyse van beroepstaken in plaats van conceptuele kennis; propageert het gebruik van hele, integratieve leertaken waarin de complexiteit van het domein weerspiegeld wordt en streeft naar integratie van vakinhoudelijke en generieke competenties. Vervolgens beschrijf ik het aldus ontworpen onderwijs als opgebouwd uit vier samenhangende componenten: (1) leertaken, (2) ondersteunende informatie, (3) procedurele informatie en (4) deeltaakoefening. In de vijfde paragraaf ga ik na wat de gepresenteerde visie op onderwijs en onderwijsontwerp betekent voor het Maastrichtse systeem van probleemgestuurd onderwijs (PGO) - wat zijn de overeenkomsten en verschillen en in welke richting is vernieuwing van $P G O$ mogelijk en gewenst? De zesde paragraaf gaat vervolgens in op het belang van 
een leven lang leren: Hoe kunnen de daarvoor vereiste competenties het beste tot ontwikkeling gebracht worden? Ik beëindig mijn rede met een beschrijving van de belangrijkste conclusies en enige suggesties voor toekomstig onderzoek.

\section{Het Gezondheidsdomein}

Voor het naar behoren uitoefenen van bijna alle beroepen in het gezondheidsdomein dient sprake te zijn van een combinatie van vaardigheden, kennis en houdingen. Vooral sociale en communicatieve vaardigheden zijn in het gezondheidsdomein erg belangrijk; de meeste medische fouten zijn bijvoorbeeld terug te voeren op gebrekkige communicatie tussen artsen en patiënten en tussen artsen onderling (Groopman, 2008). Stel dat $u$ een chirurgische ingreep moet ondergaan. $U$ mag kiezen uit een chirurg die (a) uitstekende technische vaardigheden bezit maar weinig kennis heeft van het menselijk lichaam, (b) alles weet van het menselijk lichaam maar twee linkerhanden heeft, (c) voldoende kennis en vaardigheden heeft maar een hork is met een vijandige houding tegenover zijn patiënten en collega's, of (d) tien jaar geleden op alle bovengenoemde punten goed functioneerde maar zijn kennis en vaardigheden niet meer heeft bijgehouden. Deze vraag laat zien dat het niet productief is om een strikt onderscheid te maken tussen kennis, vaardigheden en houdingen. Professionals in het gezondheidsdomein beschikken juist over complexe vaardigheden of professionele competenties waarin kennis-, vaardigheidsen houdingsaspecten gecombineerd zijn. Operatieve ingrepen kunnen domweg niet naar behoren worden uitgevoerd zonder te beschikken over grondige kennis van het menselijk lichaam en zonder te beschikken over de communicatieve vaardigheden om klachten van patiënten helder te krijgen en samen te kunnen werken in een team.

Professionals in het gezondheidsdomein worden ook geconfronteerd met snelle technologische ontwikkelingen in hun beroep, zoals nieuwe apparatuur, nieuwe medicijnen en nieuwe diagnose- en behandelmethoden.Een algemeen verschijnsel is dat computers en andere machines routine-aspecten van beroepstaken overnemen (het meten van hartslag, bloeddruk, bloedsuiker e.d. kunnen patiënten tegenwoordig eenvoudig zelf doen), zodat taken waarbij probleemoplossen, redeneren en beslissen centraal staan voor professionals steeds meer in belang toenemen. Nieuwe 
technologieën doen ook een beroep op geheel nieuw te ontwikkelen competenties. Denk daarbij bijvoorbeeld aan nieuwe beeldvormende technieken (CT scan, MRI) die 3D-technologie gebruiken of nieuwe apparatuur die minimaal-invasieve (endoscopische) chirurgische ingrepen mogelijk maakt. Zulke ontwikkelingen bieden betere diagnose- en behandelmogelijkheden en voordelen voor patiënten, maar de gebruikers moeten nieuwe competenties ontwikkelen om er optimaal gebruik van te maken. Simulaties en patiënt-simulatoren met een hoge natuurgetrouwheid kunnen de trainingsmogelijkheden bieden om hierin te voorzien.

Een bijkomend probleem van nieuwe technologie is dat deze het ook wel eens laat afweten.Studenten en professionals moeten dus niet alleen leren hoe ermee om te gaan maar ook hoe veilig te handelen in geval de technologie faalt.

Tot slot worden professionals in het gezondheidsdomein niet alleen geconfronteerd met technologische ontwikkelingen maar ook met maatschappelijke veranderingen die een duidelijke weerslag op hun beroepsuitoefening hebben. De houding van patiënten ten opzichte van hun arts en de manier waarop patiënten denken over en praten tegen hun arts is de laatste decennia sterk veranderd. Patiënten zijn mondiger geworden en dankzij de digitale revolutie in staat om veel informatie over hun klachten en mogelijke behandelwijzen op het internet te vinden. Het eerste huisartsbezoek heeft nu dikwijls het karakter van het vragen van een second opinion - na de first opinion van Google. Om bij de huisarts te blijven: Deze kan zich niet langer beperken tot het zorg dragen voor de fysieke, psychologische en sociale aspecten van het welzijn van zijn of haar patiënten, maar wordt ook geconfronteerd met een steeds gevarieerder klantenbestand van patiënten met verschillende culturele achtergronden, een niet aflatende stroom met nieuwe medicijnen en behandelmethoden, en allerlei zaken die te maken hebben met registratie, aansprakelijkheid, verzekeringen et cetera. Concluderend kan gesteld worden dat professionals in het gezondheidsdomein over zowel complexe vaardigheden of professionelecompetentiesalsover (generieke) levenlanglerencompetenties moeten beschikken om optimaal om te gaan met snelle technologische en maatschappelijke ontwikkelingen. Onderwijs en opleidingen in het gezondheidsdomein moeten daarop inspelen. 


\section{Innovatief Ontwerpen}

Sinds de Tweede Wereldoorlog in de vorige eeuw baseren de meeste modellen voor het ontwerpen van onderwijs zich op de idee dat verschillende leerdoelen verschillende onderwijsmethoden vereisen (de conditions of learning; Gagné, 1968). In dit 'leerdoelenmodel' wordt nieuw te onderwijzen leerstof beschreven in afzonderlijke leerdoelen, waarna voor elk afzonderlijk leerdoel de meest geschikte onderwijsmethode wordt gekozen. Als het leerdoel bijvoorbeeld betrekking heeft op het gebruiken van een procedure worden de stappen van de procedure gepresenteerd, een of meer demonstraties van het gebruik van de procedure gegeven, waarna de procedure wordt geoefend door de student; als het leerdoel betrekking heeft op het onthouden van een concept wordt een label (woord of symbool) voor het concept gepresenteerd, de kenmerken van het concept beschreven, waarna de student het concept in eigen woorden moet beschrijven. Deze modellen werken goed als de leerstof beschreven kan worden in leerdoelen die niet zo veel met elkaar te maken hebben. Dan kan leerdoel voor leerdoel worden onderwezen ('stukje bij beetje') en het geeft niet dat geen of weinig aandacht wordt besteed aan de relaties tussen de leerdoelen. Maar complexe domeinen worden juist gekarakteriseerd door 'geïntegreerde leerdoelen' die zeer nauw met elkaar samenhangen. Zoals beschreven in de vorige paragraaf is het gezondheidsdomein bij uitstek een domein waar complexe kennisstructuren en vaardigheden centraal staan. Het leerdoelenmodel werkt daar dan ook niet goed en moet vervangen worden door een andere aanpak.

Hoe ziet zo'n andere aanpak eruit? Ik zal in deze rede verkondigen dat een holistische ontwerpaanpak vereist is. Deze (a) start vanuit een analyse van beroepstaken in plaatsvan hetopstellenvan leerdoelen,(b) propageert het gebruik van hele integratieve leertaken waarin de complexiteit van het domein weerspiegeld wordt, en (c) streeft naar integratie van vakinhoudelijke en generieke competenties. Een cognitieve taakanalyse van beroepstaken levert minimaal vier resultaten op (Clark, Feldon, van Merriënboer, Yates, \& Early, 2008). Eerst wordt een beschrijving gegeven van alle vaardigheden of competenties die nodig zijn om de beroepstaken naar behoren uit te voeren. Dit kan beschreven worden in de vorm van een vaardighedenhiërarchie of competentiemap, om de relaties tussen de samenstellende vaardigheden en de noodzaak van coördinatie van deze vaardigheden expliciet te maken. Ten tweede 
wordt een beschrijving gegeven van de factoren die de moeilijkheid van beroepstaken, en daarmee ook de benodigde kennis, vaardigheden en houdingen op elk niveau van moeilijkheid, bepalen. Ten derde wordt een beschrijving gegeven van de kennis die nodig is om niet-routineaspecten van beroepstaken (probleemoplossen, redeneren, beslissen) tekunnen uitvoeren: Mentale modellen van het taakdomein en cognitieve strategieën om taken in dit domein op een systematische manier te benaderen. Tot slot wordt een beschrijving gegeven van de routineaspecten van taakuitvoering en de vereiste voorkennis om deze routines snel en foutloos te kunnen uitvoeren.

Een cognitieve taakanalyse leidt dus niet tot een lijst met afzonderlijke leerdoelen maar tot een integratieve, samenhangende beschrijving van alles wat nodig is om beroepstaken naar behoren te kunnen uitvoeren. In een holistische ontwerpaanpak weerspiegelen ook de leertaken deze samenhang en complexiteit van het domein (Janssen-Noordman, van Merriënboer, van der Vleuten, \& Scherpbier, 2003, 2006). Goede leertaken worden ontworpen met authentieke beroepstaken in het achterhoofd en voorkomen zo fragmentatie en compartimentalisatie van het leerproces. Ze voorkomen fragmentatie omdat ze zich richten op geïntegreerde leerdoelen; bij het uitvoeren van een authentieke betekenisvolle taak gaat het immers nooit om een enkel leerdoel, zoals het onthouden van één concept of het toepassen van één principe, maar om geïntegreerde leerdoelen. Goede leertaken voorkomen ook compartimentalisatie van het leerproces in kennis, vaardigheden en houdingen. In traditioneel onderwijs wordt kennis bijvoorbeeld onderwezen in hoorcolleges, vaardigheden in practica en houdingen - als ze überhaupt onderwezen worden - in rollenspelen. In een holistische aanpak, echter, wordt bij voorkeur gebruik gemaakt van integratieve leertaken die een simultaan beroep doen op zowel kennis-, vaardigheids- als houdingsaspecten.

Tot slot streeft een holistische aanpak naar integratie van vakinhoudelijke competenties en generieke competenties, zoals zelfstandige oordeelsvorming (relevante bronnen zoeken, afwegingen maken in complexe en dynamischesituaties) en leervaardigheden (zelfgestuurd leren,'deliberate practice' op de werkplek). Deze generieke competenties zijn vooral belangrijk om een leven lang te blijven leren, wat essentieel is in het zeer snel veranderende gezondheidsdomein. Onderzoek heeft herhaaldelijk aangetoond dat het geïsoleerd onderwijzen van generieke competenties niet tot de gewenste effecten leidt. Als men studenten bijvoorbeeld wil 
onderwijzen om zelfstandig relevante bronnen te zoeken is het niet effectief om ze daarvoor een afzonderlijke cursus te geven; het is veel doelmatiger om het zoeken van bronnen tot een integraal onderdeel van het gehele onderwijsproces te maken en de studenten deze generieke competentie, door oefening en het verwerken van feedback, door het gehele curriculum heen geleidelijk te laten ontwikkelen (Wopereis \& van Merriënboer, in druk).

\section{Innovatief Onderwijs}

Het viercomponenten model (Four-Component Instructional Design of 4C/ID; van Merriënboer \& Kirschner, 2007) beschrijft innovatief onderwijs dat is opgebouwd uit vier componenten: (1) leertaken,(2) ondersteunende informatie,(3) procedurele informatieen (4) deeltaakoefening (zieFiguur). Het model richt zich op het onderwijzen van complexe vaardigheden en professionele competenties zoals die in het gezondheidsdomein veel voorkomen.

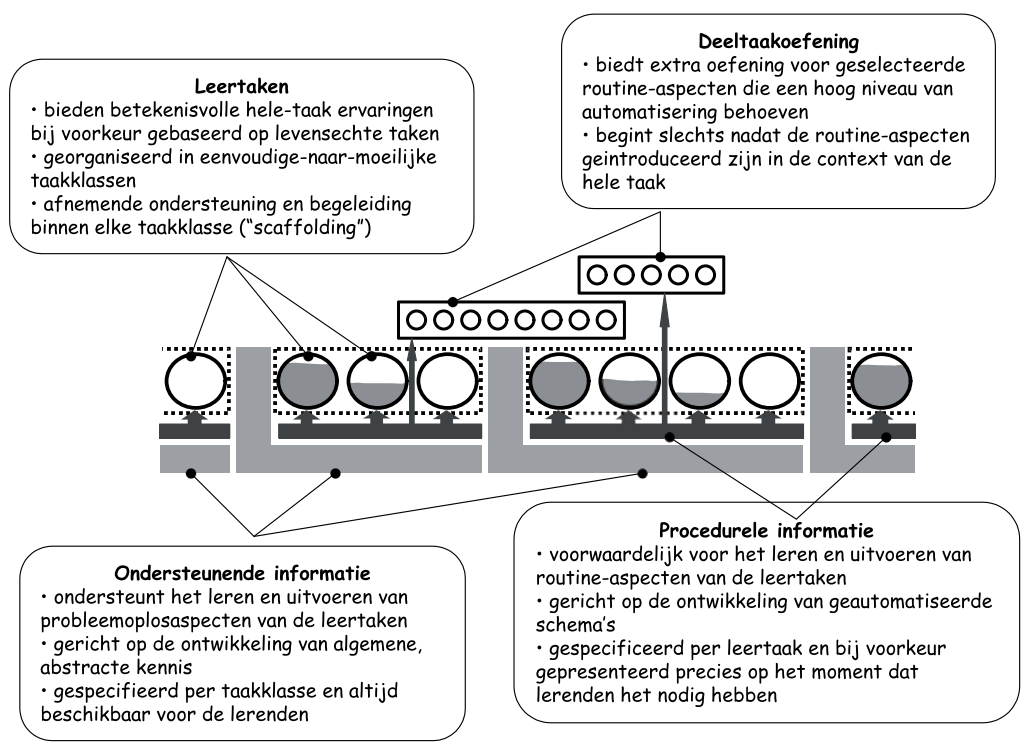




\section{Leertaken}

Leertaken vormen de kern van het onderwijs (zie de grote cirkels in de Figuur); dit kunnen bijvoorbeeld casussen, projecten, opdrachten, beroepstaken of PGO-problemen zijn. Studenten voeren de taken uit in een gesimuleerde of in de echte taakomgeving; een gesimuleerde leeromgeving kan een natuurgetrouwe ('high-fidelity') simulatie van een patiënt bieden in de vorm van een computergestuurde mannequin of een simulatiepatiënt maar kan studenten ook laten werken aan een 'low-fidelity' casus met een patiëntbeschrijving op papier. De leertaken zijn bij voorkeur hele taken: Zij confronteren studenten op een geïntegreerde wijze met vaardigheids-, kennis- en houdingsaspecten die ook in het latere beroep van belang zijn. Bovendien gaat het zowel om routineaspecten als om niet-routineaspecten bij het uitvoeren van de taak (redeneren, beslissen, probleemoplossen). Leertaken richten zich op een basaal leerproces dat inductief leren genoemd wordt; studenten leren vooral door te doen en door te ervaren hoe het is om de taken uit te voeren. Om dit proces van inductief leren optimaal te laten plaats vinden is variatie over leertaken van het grootste belang. De leertaken moeten op alle dimensies van elkaar verschillen waarop taken in de beroepspraktijk ook van elkaar verschillen. Dit maakt het voor studenten mogelijk om op basis van ervaring cognitieve schema's te ontwikkelen die representeren welke kenmerken geen invloed hebben op de wijze van taakuitvoering (oppervlaktekenmerken) en welke kenmerken dat juist wel hebben (structurele kenmerken).

Om cognitieve overbelasting te voorkomen beginnen studenten met het uitvoeren van relatief eenvoudige leertaken die, naarmate hun expertise toeneemt, steeds moeilijker worden (van Merriënboer \& Sweller, 2005,2010 ). Het begrip taakklasse duidt een verzameling van ongeveer even moeilijke taken aan, die overigens wel van elkaar verschillen op alle dimensies waarop taken in de beroepspraktijk ook van elkaar verschillen (zie de gestippelde lijnen rond de cirkels in de Figuur). De eerste taakklasse bevat bijvoorbeeld leertaken die gebaseerd zijn op de meest eenvoudige taken die een beroepsbeoefenaar in de praktijk kan tegenkomen; de laatste taakklasse bevat leertaken die gebaseerd zijn op de moeilijkste taken die een beginnend beroepsbeoefenaar in de praktijk kan tegenkomen.

Studenten zullen dikwijls hulp of begeleiding krijgen bij het werken aan de leertaken (zie de vulling van de cirkels in de Figuur). Als studenten voor het eerst gaan werken aan moeilijker taken, dus naar een volgende taakklasse gaan, krijgen zij aanvankelijk veel hulp. Binnen de taakklasse met 
even moeilijke taken neemt deze hulp geleidelijk af in een proces dat 'scaffolding' genoemd wordt - naar analogie van een steiger die wordt afgebroken terwijl het gebouw wordt opgebouwd (van Merriënboer, Kirschner, \& Kester, 2003). Als studenten de laatste taken binnen een taakklasse zonder hulp naar behoren uitvoeren kunnen zij aan moeilijker taken gaan werken, dus naar een volgende taakklasse gaan. Dan begint het proces van 'scaffolding' opnieuw, waardoor een zaagtand patroon van hulp door het hele onderwijsprogramma ontstaat. De hulp kan geboden worden door verschillende soorten leertaken te gebruiken: Studenten kunnen bijvoorbeeld eerst casussen bestuderen, dan taken gedeeltelijk uitvoeren en pas na de nodige oefening taken geheel zelfstandig uitvoeren. Maar hulp kan ook geboden worden door externe hulpmiddelen, zoals een proceswerkblad dat studenten stapsgewijs en door het stellen van leidende vragen door het proces van taakuitvoering leidt.

\section{Ondersteunende Informatie}

Bij het uitvoeren van leertaken spelen zowel routineaspecten als niet-routineaspecten een rol. Ondersteunende informatie (in de figuur afgebeeld als grijze L-vormen) helpt studenten bij het uitvoeren van de niet-routineaspecten; het gaat daarbij om taakaspecten waarbij probleemoplossen, redeneren of beslissen noodzakelijk is. De ondersteunende informatie wordt door docenten vaak 'de theorie' genoemd en in tekstboeken of hoorcolleges gepresenteerd. Het beschrijft (1) hoe het taakdomein georganiseerd is en (2) hoe problemen in het taakdomein op een systematische manier aangepakt kunnen worden (d.w.z., hoe de eigen acties in het domein georganiseerd zijn). De organisatie van het taakdomein wordt doorgaans beschreven in conceptuele, structurele en causale modellen. In het geneeskundig domein gaat het bijvoorbeeld om kennis van verschillende symptomen (conceptuele kennis - wat is dit?), om kennis van de bouw van het menselijk lichaam (structurele kennis - hoe zit dit in elkaar?) en om kennis van de werking van het hart en andere organen (causale kennis - hoe werkt dit?). De organisatie van eigen acties in het taakdomein wordt beschreven in systematische probleemaanpakken. Zulke aanpakken benoemen de achtereenvolgende fasen en subfasen in een probleemoplosproces (bijv. diagnostische fase, behandelfase, nazorgfase) en beschrijven devuistregels die behulpzaam kunnen zijn bij het succesvol voltooien van iedere fase. Een systematische aanpak kan geïllustreerd worden door een expert die een niet-triviale taak uitvoert en tegelijkertijd uitlegt hoe de taak is georganiseerd en waarom bepaalde beslissingen genomen worden. De chirurg die een operatie uitvoert en tegelijkertijd 
zijn werkwijze toelicht voor een meekijkende AIOS (Assistent In Opleiding tot Specialist) is hiervan een goed voorbeeld.

Ondersteunende informatie legt de link tussen wat studenten al weten (voorkennis) en de kennis dieze nodig hebben om niet-routineaspectenvan leertaken te kunnen uitvoeren. Onderwijsmethoden voor de presentatie van ondersteunende informatie bevorderen de constructie van cognitieve schema's door elaboratie ('verrijking'), dat wil zeggen, de informatie wordt zo gepresenteerd dat deze studenten helpt om betekenisvolle relaties te leggen tussen de nieuw gepresenteerde informatie-elementen en de voorkennis die zijal bezitten. Elaboratie is een basaalleerproces dat leidt tot rijke cognitieve schema's die begrip van complexe zaken mogelijk maken: Studenten vormen mentale modellen van het domein en cognitieve strategieën voor het aanpakken van problemen in het domein. De ondersteunende informatie is identiek voor alle leertaken in dezelfde taakklasse; deze taken zijn even moeilijk en doen een beroep op dezelfde kennisbasis. De ondersteunende informatie wordt in de figuur dan ook niet gekoppeld aan individuele leertaken maar aan de taakklassen: Het kan gepresenteerd worden voordatstudenten aan de leertakengaan werken(onderhet motto 'eerst de theorie en pas dan de praktijk') en/of het kan beschikbaar gesteld worden aan studenten die al aan de leertaken werken (onder het motto 'duik pas in de theorie als dat nodig is'). De ondersteunende informatie voor iedere volgende taakklasse is een uitbreiding op, of een verdere verdieping van de eerder gepresenteerde informatie en stelt de studenten dus in staat dingen te doen waartoe ze daarvoor nog niet in staat waren. Deze opbouw van eenvoudige naar moeilijker taken, gekoppeld aan steeds meer of steeds meer gedetailleerde kennis van het domein, wordt in het onderwijs ook wel het spiral curriculum genoemd (Bruner, 1960).

\section{Procedurele Informatie}

Procedurele informatie (in de figuur afgebeeld als donkere balk met pijlen naarde leertaken)helptstudenten bijhet uitvoerenvan de routineaspecten van leertaken; het gaat daarbij om taakaspecten die bij elke leertaak op precies dezelfde wijze worden uitgevoerd. Procedurele informatie wordt ook wel just-in-time informatie genoemd en kan bijvoorbeeld de vorm hebben van stap-voor-stap aanwijzingen die door een docent of door een gebruikershandleiding aan een student gegeven worden. Het voordeel van een docent boven een gebruikershandleiding is dat de docent over de schouder van de student kan meekijken en informatie en correctieve feedback kan verschaffen op precies het moment dat de student deze 
nodig heeft om de taak correct uit te voeren. Procedurele informatie voor een bepaald routineaspect wordt bij voorkeur aangeboden tijdens de eerste leertaak waarbij de routine door de student zelf moet worden uitgevoerd. In de daarop volgende leertaken wordt de presentatie van de procedurele informatie afgebouwd in een proces dat 'fading' wordt genoemd; de student heeft de informatie dan niet meer nodig omdat de routine al voldoende wordt beheerst.

De procedurele informatie wordt altijd gespecificeerd op het beginniveau van de studenten, dat wil zeggen, op een niveau dat begrijpelijk is voor de student met het laagste niveau van bekwaamheid. Onderwijsmethoden voor de presentatie van procedurele informatie richten zich op een basaal leerproces dat kenniscompilatie genoemd wordt: Studenten vormen cognitieve schema's die het uitvoeren van bepaalde (cognitieve) acties koppelen aan bepaalde condities (IF... THEN ...). Deze schema's stellen studenten uiteindelijk in staat om routineaspecten van leertaken snel, foutloos en zonder bewuste controle uit te voeren. Kenniscompilatie wordt vergemakkelijkt als de noodzakelijke informatie precies op het moment dat de student deze nodig heeft in kleine eenheden wordt aangeboden en dus actief is in zijn of haar (werk)geheugen. Tijdens een chirurgische ingreep zal een goede docent-specialist een AlOS bijvoorbeeld precies op het moment dat deze het nodig heeft aanwijzingen geven over het correct vasthouden van de instrumenten, het positioneren van apparatuur en de te maken handbewegingen. Deze procedurele informatie wordt bij voorkeur just-in-time aangeboden en niet in een theorieles voorafgaand aan de ingreep; het omgekeerde is het geval voor ondersteunende informatie zoals anatomische kennis.

\section{Deeltaakoefening}

Deleertakendoeneen beroepopzowel routineals niet-routineaspectenvan een complexe vaardigheid en bieden in de regel voldoende mogelijkheden om ook de routineaspecten voldoende te oefenen. Deeltaakoefening (in de figuur afgebeeld als de kleine cirkels) wordt dan ook alleen toegepast als een zeer hoge mate van automatisering van bepaalde routineaspecten noodzakelijk is en de leertaken de noodzakelijke hoeveelheid oefening niet kunnen bieden. Bekende voorbeelden van deeltaakoefening vinden we bij het leren rekenen op de basisschool, waar realistische leertaken (bijv. betalen in een winkel) centraal staan maar daarnaast als deeltaakoefening ook de tafels van vermenigvuldiging nog eens extra geoefend worden, of het leren spelen van een muziekinstrument, waar het spelen 
van muziekstukken centraal staat maar daarnaast als deeltaakoefening ook de toonladders nog eens extra geoefend worden. In het gezondheidsdomein kunnen we denken aan routines zoals het hechten van een wond, het boren van een kies of het toepassen van hartmassage.

Onderwijsmethodenvoor deeltaakoefening richten zich op versterking van cognitieve schema's door herhaling en langdurige oefening. Versterking iseen basaal leerproces dat uiteindelijkleidt totvollediggeautomatiseerde schema's. Het is belangrijk dat pas met deeltaakoefening wordt begonnen nadat een geschikte cognitieve context is gecreëerd, dat wil zeggen, nadat studenten kennis hebben gemaakt met het routineaspect in de context van hele, betekenisvolle leertaken. Dit geeft hen de mogelijkheid om de activiteiten te identificeren die nodig zijn om de routines te integreren in de hele taken. De procedurele informatie die specificeert hoe het routineaspect moet worden uitgevoerd kan al in de context van hele taken worden gepresenteerd, maar daarnaast ook nog eens tijdens de deeltaakoefening worden aangeboden (zie de lange, omhoog gerichte pijlen in de figuur). Eventuele deeltaakoefening kan het beste worden afgewisseld met het werken aan de leertaken ('intermix training') om integratie van de ontwikkelde kennisbasis te bevorderen. Voor routines waarbij niet alleen accuratesse van belang is maar ook de snelheid en het vermogen om ze te combineren met andere activiteiten, kunnen de uitvoeringscriteria tijdens deeltaakoefening geleidelijk veranderen van (1) accuratesse, naar (2) accuratesse gecombineerd met snelheid, naar (3) accuratesse gecombineerd met snelheid onder toenemende werkdruk.

\section{Het Geïntegreerde Curriculum en Transfer}

In het bovenstaande heb ik betoogd dat innovatief onderwijs dat gericht is op het onderwijzen van complexe vaardigheden of professionele competenties is opgebouwd uit vier componenten, gericht op vier basale leerprocessen: Leertaken richten zich op inductief leren, ondersteunende informatie richt zich op elaboratie, procedurele informatie richt zich op kenniscompilatie en deeltaakoefening richt zich op versterking. In een geïntegreerd curriculum staan de onderlinge relaties tussen deze componenten en leerprocessen centraal. De ondersteunende informatie is gekoppeld aan klassen van gevarieerde maar even moeilijke leertaken en is voor studenten beschikbaar voordat en/of terwijl zij aan de leertaken werken; de procedurele informatie is gekoppeld aan individuele leertaken en wordt bij voorkeur precies op het moment dat studenten het nodig hebben (just-in-time) aangeboden; deeltaakoefening voor een bepaald 
routineaspect begint nadat dit aspect geïntroduceerd is in een betekenisvolle leertaak en wordt daarna bij voorkeur afgewisseld met het werken aan de leertaken. Het ontwikkelen van een geïntegreerd curriculum is vergelijkbaar met het construeren van een skelet (zie de foto met de reconstructie van een walvisskelet op de voorpagina). Eerst wordt de ruggengraat geconstrueerd die bestaat uit leertaken, zorgvuldig geordend van eenvoudig (de kop) naar moeilijk (de staart). De ondersteunende informatie, procedurele informatie en deeltaakoefening worden vervolgens op de juiste plek aan deze ruggengraat gekoppeld. Als de koppelingen aan de ruggengraat niet op de juiste plekken worden aangebracht vermindert dit de samenhang in het curriculum, met negatieve effecten op het leerproces van de studenten.

Volgens het 4C/ID model is een geïntegreerd curriculum een voorwaarde om transfer van het geleerde te bereiken, dat wil zeggen, om ervoor te zorgen dat studenten ook in staat zijn om het geleerde in nieuwe probleemsituaties binnen en buiten de opleiding (in het bijzonder, op de werkplek) toe te passen. Hiervoor zijn drie redenen (van Merriënboer, Kester, \& Paas, 2006). In de eerste plaats zorgen hele leertaken die geïntegreerde leerdoelen nastreven en een beroep doen op zowel kennis-, vaardigheids- als houdingsaspecten ervoor dat een rijke, geïntegreerde kennisbasis wordt ontwikkeld die de kans vergroot dat er in nieuwe situaties bruikbare kennis in het geheugen gevonden kan worden. In de tweede plaats zorgt de opbouw van makkelijke naar moeilijke leertaken, in combinatie met afnemende ondersteuning en begeleiding, ervoor dat studenten leren om verschillende vaardigheidsaspecten met hun geassocieerde kennis- en houdingsaspecten te coördineren; dit stelt hen in staat om deze aspecten in nieuwe probleemsituaties en op de werkplek op een strategische manier te combineren. Tot slot zorgt het onderscheid tussen de ontwikkeling van routineaspecten en niet-routineaspecten ervoor dat studenten de bekende aspecten van problemen moeiteloos kunnen oplossen omdat zij daarvoor over de routines beschikken, waardoor zij over extra cognitieve bronnen beschikken voor het uitvoerenvandeniet-routineaspecten (redeneren, probleemoplossen, beslissen) en het reflecteren op de kwaliteit van de gevonden oplossing. 


\section{PGO Revisited}

De Universiteit Maastricht is nationaal en internationaal bekend door zijn probleemgestuurd onderwijs (PGO). Wat zijn nu de overeenkomsten en verschillen tussen innovatief onderwijs zoals ontworpen met het 4 C/ID model en het Maastrichtse PGO? De overeenkomsten springen in het oog. De leertaken zijn de problemen die besproken worden in de onderwijsgroep; deze problemen zijn bij voorkeur authentiek en zetten studenten aan tot activatie van voorkennis, analyse van het probleem en formuleren van leerdoelen. De ondersteunende informatie wordt binnen het PGO gevonden in het studielandschap (bibliotheek) of aangeboden in colleges. De deeltaakoefening wordt vooral verzorgd in het skillslab, waar allerlei vaardigheden uitvoerig geoefend kunnen worden. En de procedurele informatie wordt in de onderwijsgroep verstrekt door de tutor en in het skillslab door de instructeur en/of allerlei ter plekke beschikbare procedure-beschrijvingen. Het Maastrichtse PGO kan dus eenvoudig afgebeeld worden op de vier componenten.

Toch zijn er ook opvallende verschillen, die vooral te maken hebben met het feit dat PGO een onderwijsmodel is en 4C/ID een ontwerpmodel, dat meer ruimte laat voor afstemming op de doelgroep (bijv. voorkennis, expertiseniveau), gewenste leeruitkomsten en context. De belangrijkste verschillen hebben te maken met (a) de aard van de leertaken, (b) de organisatie van de leertaken en (c) de mate van integratie. In het PGO hebben leertaken bijna altijd de vorm van problemen die een bepaald fenomeen beschrijven en waarbij “...the task of a group of students is to explain these phenomena in terms of underlying processes. Explanations take the form of physical, biological or psycho-social mechanisms that may be underlying the phenomena concerned" (Schmidt, 1983, p. 13). Ook in onderwijs dat ontworpen is met 4C/ID kunnen zulke problemen een rol spelen, maar daarnaast wordt een veelheid van andere bruikbare leertaken onderscheiden zoals casebeschrijvingen, projecten, simulatieopdrachten en beroepstaken. In het geneeskundedomein bieden elektronische virtuele patiënten (E-VIPs; Huwendiek et al., 2009) bijvoorbeeld de mogelijkheid om interactief diagnoses te stellen en een behandelplan op te stellen en bieden computergestuurde mannequins de mogelijkheid om complexe (team)taken te oefenen. Dit maakt het mogelijk om de natuurgetrouwheid van leertaken geleidelijk te doen toenemen naarmate studenten meer expertise opbouwen, van bijvoorbeeld klassieke PGOproblemen, via elektronische virtuele patiënten en simulatiepatiënten, naar beroepstaken met echte patiënten (Maran \& Glavin, 2003). 
Een tweede verschil betreft de organisatie van de leertaken. In PGO wordt veel aandacht besteed aan de vormgeving van de leertaken en de wijze waarop deze in de onderwijsgroep behandeld worden volgens de zogenaamde 'zevensprong' (Wood, 2003), maar er is weinig oog voor de relaties tussen de verschillende leertaken binnen een onderwijsblok of tussen onderwijsblokken. Onderwijs dat ontworpen is volgens $4 \mathrm{C} / \mathrm{ID}$ benadrukt juist het belang van toenemende moeilijkheid van de leertaken om het proces van competentieontwikkeling optimaal te ondersteunen. Tabel 1 geeft als voorbeeld een beschrijving van leertaken in studiejaar 2 en 3 van de opleiding gezondheidswetenschappen; deze leertaken zijn geïntegreerd in verschillende blokken en richten zich op de ontwikkeling van onderzoekscompetenties (met dank aan Herma Roebertsen die deze Tabel heeft gemaakt).Zo mogelijkworden leertakenopeen bepaald niveau van moeilijkheid meerdere keren door de studenten uitgevoerd, om hen optimaal te laten profiteren van de geboden oefening. Dan is er bij voorkeur sprake van afnemende hulp en begeleiding: Studenten bestuderen bijvoorbeeld eerst hoe de taak wordt uitgevoerd door iemand anders, voeren dan delen van de taak uit en voeren pas daarna de gehele taak zelfstandig uit. Tot slot zorgt het 4C/ID model er voor dat de variabiliteit over leertaken gewaarborgd is. Goed ontworpen leertaken verschillen van elkaar op zowel oppervlaktekenmerken, zodat studenten leren welke kenmerken niet relevant zijn voor de wijze van taakuitvoering, als structurele kenmerken, zodat zij ook leren welke kenmerken de wijze waarop de taak wordt uitgevoerd wel beïnvloeden. Ook in het PGO zullen problemen vaak op oppervlakte en structurele kenmerken van elkaar verschillen maar daar ligt geen systematische analyse aan ten grondslag.

Tabel 1. Leertaken gericht op de ontwikkeling van onderzoekscompetenties in studiejaar 2 en 3 van de opleiding Gezondheidswetenschappen.

\begin{tabular}{|l|l|l|}
\hline Leertaak & In blok & Feedback \\
\hline $\begin{array}{l}\text { 1. Orientatie op wetenschappelijke literatuur; } \\
\text { kritisch lezen van wetenschappelijk artikel }\end{array}$ & 2.1 & $\begin{array}{l}\text { Feedback van tutor in } \\
\text { onderwijsgroep }\end{array}$ \\
\hline $\begin{array}{l}\text { 2. Artikel over bepaald aspect van de gezond- } \\
\text { heidszorg; kritisch beoordelen op inhoud en } \\
\text { methodologische en statistische onderbouwing; } \\
\text { mondeling presenteren. }\end{array}$ & 2.3 & $\begin{array}{l}\text { Feedback door tutor } \\
\text { en peers; onderdeel } \\
\text { van blokbeoordeling }\end{array}$ \\
\hline
\end{tabular}




\begin{tabular}{|c|c|c|c|}
\hline & $\begin{array}{l}\text { Analyseren 2-3 artikelen over een voor het blok } \\
\text { relevant vraagstuk. Dit op grond van weten- } \\
\text { schapsfilosofie; gekozen methode voor analyse } \\
\text { en mate van statistische onderbouwing; } \\
\text { schriftelijk presenteren. }\end{array}$ & 2.5 & $\begin{array}{l}\text { Feedback op opzet } \\
\text { door peers en tutor; } \\
\text { onderdeel van } \\
\text { blokbeoordeling. }\end{array}$ \\
\hline & $\begin{array}{l}\text { Opzet maken voor onderzoeksvraag en me- } \\
\text { thode; theoretische inkadering. }\end{array}$ & 2.6 & $\begin{array}{l}\text { Feedback door } \\
\text { blokplanningsgroep; } \\
\text { onderdeel van } \\
\text { blokbeoordeling. }\end{array}$ \\
\hline & $\begin{array}{l}\text { 'Critical appraisal' maken over een bepaald } \\
\text { artikel dat inhoudelijk past in het blok. }\end{array}$ & 3.3 & $\begin{array}{l}\text { Feedback door } \\
\text { blokplanningsgroep; } \\
\text { onderdeel van } \\
\text { blokbeoordeling. }\end{array}$ \\
\hline & $\begin{array}{l}\text { Opzet maken voor de bachelor thesis; } \\
\text { deze presenteren in het Engels }\end{array}$ & 3.4 & $\begin{array}{l}\text { Feedback door tutor } \\
\text { en peers; onderdeel } \\
\text { van blokbeoordeling. }\end{array}$ \\
\hline & $\begin{array}{l}\text { Bachelor thesis schrijven en inhoud } \\
\text { presenteren. }\end{array}$ & 3.6 & $\begin{array}{l}\text { Feedback door } \\
\text { begeleider bachelor } \\
\text { thesis. }\end{array}$ \\
\hline
\end{tabular}

Het derde verschil tussen PGO en 4C/ID betreft de vormgeving van het geïntegreerde curriculum (cf. het walvisskelet van de foto). Integratie heeft hierbij betrekking op (a) de leerdoelen, (b) de vier componenten, en (c)vakinhoudelijkeengeneriekecompetenties. Het4C/ID model benadrukt het belang van geïntegreerde leerdoelen en dus het gebruik van leertaken die zowel een beroep doen op kennis-, vaardigheids- als houdingsaspecten. Voor PGO-problemen is dat niet altijd het geval; in het Maastrichtse systeem zijn deze vooral op kennisontwikkeling gericht. Voor de vier componenten hanteert het 4C/ID model de leertaken als ruggengraat, waar de drie andere componenten op de juiste plaats aan worden gekoppeld. In het PGO systeem is de koppeling tussen leertaken (i.e., PGO-problemen) en ondersteunende informatie ook goed gewaarborgd, omdat studenten vanuit de problemen hun leerdoelen formuleren en bronnen bestuderen. De tutor in de onderwijsgroep en de instructeur in het skillslab kunnen tevens zorgen voor een goede koppeling van procedurele informatie aan respectievelijk de leertaken en de deeltaakoefening. De koppeling tussen de leertaken (PGO-problemen) en deeltaakoefening in het skillslab is in het Maastrichtse PGO echter niet altijd transparant - hier is verbetering mogelijk. Tot slot besteden zowel 4C/ID als PGO veel aandacht aan de integratie van vakinhoudelijke en generieke competenties. 
In het Maastrichtse PGO leren studenten bijvoorbeeld hun eigen leerdoelen te stellen, samen te werken in de onderwijsgroep, en relevante bronnen te zoeken en raadplegen in het studielandschap. Het 4C/ID model voegt hier generieke competenties die van belang zijn om een leven lang te blijven leren aan toe. Deze worden verder uitgewerkt in de volgende paragraaf.

\section{$6 \quad$ Een Leven Lang Leren}

Het Maastrichtse PGO richt zich van oudsher op zowel de ontwikkeling van vakinhoudelijke competenties als de ontwikkeling van generieke competenties, omdat studenten - met de nodige hulp en begeleiding samen werken aan realistische problemen, hun eigen leerproces sturen en zelfstandig bronnen zoeken. Onderzoek toont het succes daarvan aan. Vergelijkingen tussen PGOentraditionelevormenvanonderwijslatenzien dat PGO-afgestudeerden beter scoren op communicatieve vaardigheden, probleemoplossen, zelfgestuurd leren en zoeken van relevante informatie (Prince, van Eijs, Boshuizen, van der Vleuten, \& Scherpbier, 2005; Schmidt, Vermeulen, \& van der Molen, 2006). Vernieuwingen van het onderwijs dienen hierop voort te bouwen met nieuwe benaderingen die optimaal aansluiten op eisen vanuit de moderne arbeidsmarkt en maatschappij. In een snel veranderende kenniseconomie zijn vooral de competenties die vereist zijn om een leven lang te blijven leren van belang (van Merriënboer, Kirschner, Paas, Sloep, \& Caniëls, 2009). De volgende paragrafen beschrijven de generieke competenties die in het kader van een levenlang leren vereist zijn om bronnen te zoeken, het eigen leerproces vorm te geven en te (blijven) leren op de werkplek.

\section{Bronnen Zoeken}

Om een leven lang te leren moeten beginnende beroepsbeoefenaren in staat zijn om zelfstandig bronnen te zoeken die in hun leerbehoeften voorzien. In het Maastrichtse PGO krijgt dit oorspronkelijk vorm door studenten in het studielandschap schriftelijke bronnen te laten zoeken die helpen om de leerdoelen, die in de onderwijsgroep geformuleerd zijn naar aanleiding van de analyse van een PGO-probleem, te bereiken. Deze vorm van bronnen zoeken is waardevol maar (a) beperkt zich tot ondersteunende informatie terwijl bronnen voor procedurele informatie en deeltaakoefeningook belangrijkzijnvoor een proces vancomplexleren,(b) 
benadrukt schriftelijke bronnen die naspeurbaar zijn in een bibliografisch systeem terwijl hypermedia (in het bijzonder het internet, Wikipedia e.d.) steeds populairderworden,en(c) besteedweinigaandachtaanhetexpliciet onderwijzen van de vaardigheden die nodig zijn om relevante informatie zoeken ('information problem solving'). Onderzoek laat zien dat niet alleen studenten maar ook afgestudeerden grote moeite hebben met het zoeken van relevante informatie, in het bijzonder met het definiëren van het informatieprobleem (zij weten niet wat zij niet weten) en met het valideren van de betrouwbaarheid en geloofwaardigheid van gevonden bronnen (Brand-Gruwel, Wopereis, \& Vermetten, 2005). Om verandering in deze situatie te brengen moeten we studenten niet alleen relevante bronnen laten zoeken maar hen hierin ook expliciet onderwijzen; daarbij kunnen de 4C/ID principes richtinggevend zijn.

Het zoeken van bronnen met procedurele just-in-time informatie die specificeert hoe routineaspecten van leertaken moeten worden uitgevoerd verschilt fundamenteel van het zoeken van bronnen met ondersteunende informatie. Traditioneel wordt procedurele informatie tijdens het werken aan de taken gepresenteerd door een instructeur en bij afwezigheid van een instructeur door middel van handleidingen, checklists of 'quick reference guides'. Mensen zijn geneigd om het zoeken van procedurele informatie zo lang mogelijk uit te stellen, zoals verwoord in de bekende uitdrukking "...if all else fails read the manual". Dit vraagt om creatieve manieren om procedurele informatie op een eenvoudig toegankelijke wijze beschikbaar te stellen tijdens taakuitvoering. Een voorbeeld is het gebruik van een videodemonstratie van een laparoscopische ingreep (een'kijkoperatie')terwijleenAIOS dezeingreepzelfopeen patiënt uitvoert; de demonstratie-monitor laat hetzelfde beeld zien als er op de laparoscopie monitor tezien moet zijn bij het correct uitvoeren van de ingreepen de assistent wordt door visuele signalen geattendeerd op kritische stappen in de procedure. De assistent wordt dus stap voor stap door de procedure geleid en dit leidt tot verbeterde prestaties (Pierie, van Det, Lamme, Meijerink, \& Hoff, 2009). Ook mobiele technologie (smartphones, PDA's) en, in de nabije toekomst, augmented reality bieden veelbelovende mogelijkheden om procedurele informatie just-in-time, tijdens taakuitvoering te presenteren.

Tot slot heeft het zoeken van bronnen ook betrekking op het identificeren van deeltaakoefening die helpt om de uitvoering van de hele taken te verbeteren, omdat routineaspecten van de hele taken zo geautomatiseerd worden en er dus meer cognitieve capaciteit beschikbaar komt voor het 
uitvoeren van de niet-routineaspecten. Voor initiële opleidingen in het gezondheidsdomein betekent dit in de eerste plaats dat mogelijkheden voor deeltaakoefening in een skillslab flexibilisering behoeven. Studenten kunnen dan naar hun individuele behoeften deeltaken trainen en deze net zo lang trainen tot zij ze volkomen beheersen. Daarbij is het essentieel dat studenten expliciet onderwezen wordt hoe ze noodzakelijke deeltaakoefening kunnen identificeren en dat zij ook beoordeeld worden op de behaalde resultaten. $\mathrm{Na}$ de initiële opleidingen worden ook professionals geconfronteerd met nieuwe instrumenten en nieuwe diagnose- en behandelmethoden. In het kader van een leven lang leren en ten behoeve van patiëntveiligheid is training dan van het allergrootste belang. Ten behoeve hiervan komen steeds meer simulatielaboratoria beschikbaar, die zijn uitgerust met simulatoren met veelal lage natuurgetrouwheid voor deeltaakoefening ('low-fidelity part-task trainers', bijvoorbeeld box trainers voor laparoscopie) maar in toenemende mate ook met simulatoren met hoge natuurgetrouwheid voor hele-taak oefening (high-fidelity whole-task trainers, bijvoorbeeld computergestuurde mannequins in een volledige uitgeruste operatiekamer). Beginnende beroepsbeoefenaren moeten over de competenties beschikken om optimaal gebruik te maken van dergelijke faciliteiten maar ook huidige professionals dienen bewust gemaakt te worden van hun belang.

\section{Zelfgestuurd Leren}

Een leven lang leren is alleen mogelijk als studenten leren om zelfgestuurd te leren ('self-directed learning'; van Merriënboer \& Sluijsmans, 2009). Dit betekent dat zij verantwoordelijkheid leren nemen voor de gehele leercyclus: Het formuleren van gewenste, te ontwikkelen competenties en het doorlopen van een iteratief proces van actie en reflectie dat pas eindigt wanneerdezecompetentiesvolledigontwikkeldzijn.Actieheeftbetrekking op het selecteren en gebruiken van allerlei bronnen (taken, boeken, internetsites, docenten) die helpen om leerbehoeften te bevredigen; reflectie heeft betrekking op het gebruiken van cognitieve feedback en beoordelingen om de leerbehoeften aan te passen. De leerbehoeften geven in deze benadering de discrepantie weer tussen het huidige en het gewenste niveau van competentieontwikkeling; als het leerproces naar behoren verloopt wordt deze discrepantie elke iteratie kleiner. Zelfgestuurd leren binnen het 4C/ID kader betekent dan het volgende. De acties van de student betreffen het selecteren en uitvoeren van leertaken die, gegeven de individuele leerbehoefte, het juiste niveau van moeilijkheid hebben, het juiste niveau van hulp en ondersteuning bieden en tevens 
voldoende variatie waarborgen. De reflecties van de student betreffen het verzamelen van feedback en (zelf)beoordelingen om aangepaste leerbehoeften vast te stellen. Op basis van de aangepaste leerbehoeften worden dan weer nieuwe leertaken geselecteerd en uitgevoerd - en zo verder totdat uiteindelijk de gewenste competenties bereikt zijn.

Een krachtig instrument om het proces van zelfgestuurd leren te ondersteunen is een zogenaamd ontwikkelingsportfolio. Kicken, Brand-Gruwel, van Merriënboer en Slot (2009) ontwikkelden voor de opleiding van kappers een elektronisch portfolio dat vier functies vervult. Ten eerste houdt het portfolio bij aan welke leertaken de student gewerkt heeft (bijv. aanbrengen van een permanent geoefend op een pop; mannelijke klant geholpen met kort haar in laagjes; vrouwelijk model geholpen met lang haar verven en permanenten, etc.). Ten tweede worden voor elke uitgevoerde taak beoordelingen en feedbackrapporten verzameld (van klanten, docenten, medestudenten, zelfbeoordelingen). Beoordelingen kunnen gegeven worden op alle routine- en niet-routineaspecten die voor het kappersvak van belang zijn, zoals kappen (wassen, knippen, verven, permanenten, föhnen etc.), communiceren met de klant, bedienen van het kasregister, in acht nemen van veiligheidsvoorschriften en zo verder. Ten derde worden de leerbehoeften vastgesteld door de beoordelingen onderling te vergelijken en af te zetten tegen de uiteindelijk gewenste competenties. Ten slotte helpt het portfolio studenten bij het kiezen van nieuwe leertaken: Hoe kunnen nieuw te selecteren leertaken, op een gegeven niveau van moeilijkheid en met een gegeven niveau van hulp en ondersteuning, helpen om de laatst geformuleerde leerbehoeften te bevredigen?

Onderzoek wijst uit dat een ontwikkelingsportfolio het proces van zelfgestuurd leren adequaat kan ondersteunen, maar dat extra maatregelen nodig zijn om zelfgestuurd leren te leren, met andere woorden, om deze generieke competentie te onderwijzen. Dezelfde principes die 4C/ID voorschrijft voor het ontwikkelen van vakinhoudelijke competenties zijn ook geschikt voor het ontwikkelen van generieke competenties zoals zelfgestuurd leren: Ordenen van leertaken van eenvoudig naar moeilijk, bieden van hulp en ondersteuning en deze afbouwen in een proces van 'scaffolding' en zorgen voor voldoende variatie. Ordening van eenvoudig naar moeilijk kan bijvoorbeeld georganiseerd worden door de verzameling leertaken waaruit door de student gekozen kan worden geleidelijk in omvang te laten toenemen; eerst kiest de student uit een klein aantal voor- 
geselecteerde leertaken en pas later wordt gekozen uit alle mogelijke taken (Corbalan, Kester, \& van Merriënboer, 2008). Het bieden van hulp en ondersteuning kan gerealiseerd worden in regelmatige coachingsgesprekken, waarbij een docent samen met de student de beschikbare gegevens uit het ontwikkelingsportfolio bespreekt en afspraken maakt over toekomstige leertaken waaraan gewerkt gaat worden. Wat variatie betreft blijkt uit eerder onderzoek dat studenten de neiging hebben om nieuwe leertaken te kiezen die oefening bieden in vaardigheden die zij al min of meer beheersen of die zij leuk vinden; gericht advies kan hen helpen om ook taken te kiezen die een beroep doen op nieuwe vaardigheden die zij nog niet beheersen (Kicken, Brand-Gruwel, \& van Merriënboer, 2009).

\section{Werkplekleren}

Als er iets belangrijk is in het kader van een leven lang leren dan is het wel het vermogen om te leren op de werkplek. Op de werkplek voert men (beroeps)taken uit en het is dan ook verleidelijk om te denken dat leren daar wel 'vanzelf' plaats zal vinden. Dat is helaas niet het geval. Beroepstaken zijn geen leertaken: Je hebt ze niet voor het uitkiezen en het gaat niet primair om leren maar om presteren. Vooral de focus op presteren maakt het niet eenvoudig om van beroepstaken te leren. Het opdoen van ervaring op de werkplek is weliswaar een conditio sine qua non om expertise op te bouwen - waarbij wel van minimaal 10.000 uur ervaring gesproken wordt om een expertniveau te bereiken - maar het is een noodzakelijke maar geen voldoende voorwaarde. Langdurige ervaring leidt weliswaar altijd tot de automatisering van routineaspecten, maar het leidt alleen tot de ontwikkeling van cognitieve schema's die het mogelijk maken om niet-routineaspecten uit te voeren (probleemoplossen, redeneren etc.) als het gepaard gaat met een bewust cognitief proces van veralgemenisering en abstractie, een proces dat tijd vraagt en dat gedreven wordt door planning en reflectie. Professionals die geen tijd vrijmaken voor planning en reflectie leren dus onvoldoende op de werkplek.

Ericsson (2009) beschrijft deliberate practice als een leerproces dat verklaart waarom sommige professionals in domeinen zoals muziek, sport en geneeskunde de top bereiken en anderen niet. Het gaat daarbij niet alleen om de hoeveelheid oefening of ervaring maar ook om de kwaliteit van deze oefening. Deliberate practice is essentieel om op de werkplek prestatieverbetering te bereiken. Het gaat om drie activiteiten: (a) het voor jezelf formuleren van leerdoelen, (b) het verzamelen van cognitieve feedback op de kwaliteit van taakuitvoering, en (c) het op basis van de 
verzamelde feedback beoordelen of leerdoelen naderbij gekomen zijn. Het is belangrijk om op te merken dat het accent hier ligt op leren in plaats van presteren. Professionals in de sport zijn zich er vaak van bewust datleren of prestatieverbetering optermijn slechts mogelijkis door tijdelijk een stapje in prestaties terug te doen. Zo gaf de golfer Tiger Woods enige jaren geleden aan dat hij waarschijnlijk zou terugvallen in de ranglijsten omdat hij een bepaalde swing wilde verbeteren. Dat is precies wat er gebeurde maar na ruim een jaar was hij beter dan ooit en stond weer nummer 1 in de ranglijsten. Dit voorbeeld geeft ook aan dat goed ontwikkelde metacognitie (i.h.b., kennis van eigen leerprocessen) ten grondslag ligt aan deliberate practice: Daarbij gaat het in de 'forethought phase' om taakanalyse en zelf-motivatie (waaronder het formuleren van leerdoelen), in de 'performance phase' om zelf-controle en zelf-observatie (waaronder het verzamelen van feedback) en in de 'self-reflection phase' om zelf-beoordeling en zelf-reactie (waaronder het bepalen of leerdoelen naderbij gekomen zijn; Zimmerman, 2002).

Hoe kunnen we leren op de werkplek en deliberate practice nu het beste stimuleren? Hierover is nog relatief weinig bekend. De literatuur over metacognitie en in het bijzonder metacognitieve prompts biedt wel interessante aanknopingspunten. Metacognitieve prompts of 'judgements of learning' kunnen bijvoorbeeld gebruikt worden in coachingsgesprekken en roepen een professional op om stil te staan bij, dus ook tijd vrij te maken voor de verschillende metacognitieve fasen van de leercyclus (bijv. Hoe eenvoudig denk je dat dit te leren is? Hoe zeker ben je er van dat je het geleerde volgende week nog kunt gebruiken? Hoe zeker ben je er van dat dit de beste aanpak was?). Onderzoek laat zien dat metacognitieve prompts een positief effect op het leerproces kunnen hebben, mits studenten de resultaten van hun reflectie ook gebruiken voor de inrichting van het toekomstige leerproces. Zo vonden Thiede, Anderson en Therriault (2003) een positief effect van metacognitieve prompts na het bestuderen van een tekst op testprestatie, maar pas nadat de studenten in staat waren gesteld om de tekst opnieuw te bestuderen. Een voorlopige bevinding lijkt dus dat een eenzijdige nadruk op reflectie niet werkt. Het is vergelijkbaar met het gebruik van de achteruitkijkspiegel bij autorijden. Veel in de achteruitkijkspiegel kijken per se leidt niet tot beter rijgedrag; achteruit kijken krijgt pas waarde als de verzamelde informatie gebruikt wordt om toekomstige acties te plannen, met andere woorden, als het ten dienste gesteld wordt van het vooruit rijden. 


\section{Conclusies}

Mijn rede nadert zijn einde. In het eerste deel heb ik een beschrijving gegeven van het gezondheidsdomein, een domein dat wordt gekenmerkt door professionele competenties waar de combinatie van vaardigheden, kennis en houdingen centraal staat en waar sprake is van beroepen die continu veranderen als gevolg van snelle technologische en maatschappelijke ontwikkelingen. Het ontwerpen van onderwijs en opleidingen in dit domein vraagt om een holistische aanpak, waarbij wordt uitgegaan van hele, betekenisvolle taken en gestreefd wordt naar de integratie van vakinhoudelijke en generieke competenties. Onderwijs dat op deze manier ontworpen wordt bestaat altijd uit vier componenten: (a) leertaken, (b) ondersteunende informatie, (c) procedurele informatie, en (d) deeltaakoefening.

Het tweede deel van mijn rede schetste een aantal lijnen voor toekomstig onderzoek. De eerste drie onderzoekslijnen bevinden zich op het raakvlak van 4 C/ID en PGO en betreffen onderzoek naar:

- Het gebruik van alternatieve leertaken of problemen binnen het PGO, zoals elektronische virtuele patiënten, projecten en beroepstaken.

- Organisatie van leertaken of problemen in het curriculum, met een opbouw van eenvoudig naar moeilijk en, op hetzelfde niveau van moeilijkheid, afnemende hulp en begeleiding.

- Integratie in het curriculum op het niveau van leertaken, onderwijscomponenten en vakinhoudelijke en generieke competenties.

Drie complementaire onderzoekslijnen richten zich op de ontwikkeling van generieke competenties die nodig zijn voor een leven lang leren. Dit betreft onderzoek naar:

- Het zoeken van bronnen, waar het niet alleen om ondersteunende informatie gaat maar zeker ook om procedurele just-in-time informatie en om additionele oefenmogelijkheden.

- Zelfgestuurd leren en instrumenten (bijv. ontwikkelingsportfolio's) en onderwijsmethoden om zelfgestuurd leren expliciet te onderwijzen.

- Methoden om leren op de werkplek te faciliteren, zoals het aanbieden van metacognitieve prompts om deliberate practice te stimuleren.

Ik heb gezegd. 


\section{Dankwoord}

Ik wil het College van Bestuur van de Universiteit Maastricht en de Rector Magnificus, Gerard Mols, evenals de Raad van Bestuur van het MUMC+ en de Decaan van de Faculteit FHML, Martin Paul, bedanken voor het in mij gestelde vertrouwen.

Ookmijnoudeleermeesters wilik bedanken.SanneDijkstra, mijn promotor bij de Universiteit Twente, Henk Schmidt, korte tijd mijn baas en collega bij de Universiteit Maastricht, en Wim Jochems, met wie ik lange tijd heb samengewerkt bij de Open Universiteit Nederland. Bedankt. Ik heb veel van jullie geleerd.

Ik wil al mijn oud collega's bij de Open Universiteit Nederland bedanken voor de bijzonder prettige samenwerking in de afgelopen 10 jaar. Mijn nieuwe collega's bij de vakgroep Onderwijsontwikkeling en Onderwijsresearch en bij de SHE Graduate School wil ik bedanken omdat ze er voor gezorgd hebben dat ik mij heel snel thuis voelde op mijn nieuwe werkplek. Ik dank in het bijzonder Cees van der Vleuten en Albert Scherpbier voor de hele prettige manier waarop ze mij snel hebben ingewerkt.

Mijn ouders wil ik bedanken voor hun vertrouwen, liefde en nooit aflatende support. Helaas kan mijn vader deze inauguratie niet meer meemaken, maar ik weet zeker dat hij er net als 11 jaar geleden van genoten zou hebben.

Tot slot bedank ik mijn lieve Ankie en mijn kinderen Bart, Jelle en Maud. Gewoon omdat ze er altijd voor me zijn. 


\section{Referenties}

Brand-Gruwel, S., Wopereis, I. G. J. H., \& Vermetten, Y. (2005). Information problem solving by experts and novices: Analysis of a complex skill. Computers in Human Behavior, 21, 487-508.

Bruner, J. (1960). The process of education. Cambridge, MA: Harvard University Press.

Clark, R. E., Feldon, D. F., van Merriënboer, J. J. G., Yates, K. A., \& Early, S. (2008). Cognitive task analysis. In J. M. Spector, M. D. Merrill, J. J. G. van Merriënboer, \& M. P. Driscoll (Eds.), Handbook of research on educational communications and technology (3 ${ }^{\text {rd }}$ Ed.) (pp. 577-594). Mahwah, NJ: Erlbaum.

Corbalan, G., Kester, L., \& van Merriënboer, J. J. G. (2008). Selecting learning tasks: Effects of adaptation and shared control on learning efficiency and task involvement. Contemporary Educational Psychology, $33,733-756$.

Ericsson, K. A. (2009). Enhancing the development of professional performance: Implications from the study of deliberate practice. In K. A. Ericsson (Ed.), Development of professional expertise (pp. 405-431). Cambridge, MA: Cambridge University Press.

Gagné, R. M. (1968). Learning hierarchies. Educational Psychologist, 6, 1-9.

Groopman, J. E. (2008). How doctors think. New York: Houghton Mifflin Company.

Huwendiek, S., de Leng, B. A., Zary, N., Fischer, M. R., Ruiz, J. G., \& Ellaway, R. (2009). Towards a typology of virtual patients. Medical Teacher, 31, 743-748.

Janssen-Noordman, A. M. B., van Merriënboer, J. J. G., van der Vleuten, C. P. M., \& Scherpbier, A. J. J. A. (2003). Innovatief onderwijs ontwerpen: Via leertaken naar complexe vaardigheden. Tijdschrift voor Medisch Onderwijs, 22(4), 187-195.

Janssen-Noordman, A. M. B., van Merriënboer, J. J. G., van der Vleuten, C. P. M., \& Scherpbier, A. J. J. A. (2006). Design of integrated practice for learning professional competences. Medical Teacher, 28, 447-452. 
Kicken, W., Brand-Gruwel, S., \& van Merriënboer, J. J. G. (2009). The effects of portfolio-based advice on the development of self-directed learning skills in secondary vocational education. Educational Technology, Research and Development, 57, 439-460.

Kicken, W., Brand-Gruwel, S., van Merriënboer, J. J. G., \& Slot, W. (2009). Design and evaluation of a development portfolio: how to improve students' self-directed learning skills. Instructional Science, 37, 453-473.

Maran, N. J., \& Glavin, R. J. (2003). Low to high fidelity simulation: A continuum of medical Education? Medical Education, 37, 22-28.

Pierie, J. P. E. N., van Det, M. J., Lamme, B., Meijerink, W. H. J. M., \& Hoff. C. (2009). Peroperatieve video-instructie verhoogt het rendement van laparoscopische opleiding van AIOS. Paper gepresenteerd op het NVMO congres, 12-13 november 2009, Egmond aan Zee.

Prince, K. J. A. H., van Eijs, P. W. L. J., Boshuizen, H. P. A., van der Vleuten, C. P. M, \& Scherpbier, A. J. J. A. (2005). General competencies of problem-based learning (PBL) and non-PBL graduates. Medical Education, 39, 394-401.

Schmidt, H. G. (1983). Problem-based learning: Rationale and description. Medical Education, 17, 11-16.

Schmidt, H. G., Vermeulen, L., \& van der Molen, H. T. (2006). Long-term effects of problem-based learning: A comparison of competencies acquired by graduates of a problem-based and a conventional medical school. Medical Education, 40, 562-567.

Thiede, K. W., Anderson, M. C. M., \& Therriault, D. (2003). Accuracy of metacognitive monitoring affects learning of texts. Journal of Educational Psychology, 95, 66-73.

Van Merriënboer, J. J. G., Kester, L., \& Paas, F. (2006). Teaching complex rather than simple tasks: Balancing intrinsic and germane load to enhance transfer of learning. Applied Cognitive Psychology, 20, 343-352.

Van Merriënboer, J. J. G., \& Kirschner, P. A. (2007). Ten steps to complex learning. Mahwah, NJ: Erlbaum. 
Van Merriënboer, J. J. G., Kirschner, P. A., \& Kester, L. (2003). Taking the load of a learners' mind: Instructional design for complex learning. Educational Psychologist, 38(1), 5-13.

Van Merriënboer, J. J. G., Kirschner, P. A., Paas, F., Sloep, P. B., \& Caniëls, M. C. J. (2009). Towards an integrated approach for research on lifelong learning. Educational Technology Magazine, 49(3), 3-14.

Van Merriënboer, J. J. G., \& Sluijsmans, D. A. (2009). Toward a synthesis of cognitive load theory, four-component instructional design, and self-directed learning. Educational Psychology Review, 21, 55-66.

Van Merriënboer, J. J. G., \& Sweller, J. (2005). Cognitive load theory and complex learning: Recent developments and future directions. Educational Psychology Review, 17, 147-177.

Van Merriënboer, J. J. G., \& Sweller, J. (2010). Cognitive load theory in health professional education: Design principles and strategies. Medical Education, 44, 85-93.

Wood, D. F. (2003). ABC of learning and teaching in medicine: Problem based learning. British Medical Journal, 326, 328-330.

Wopereis,I. G. J. H., \& van Merriënboer, J. J. G. (in druk). Evaluating textbased information on the World Wide Web. Learning and Instruction.

Zimmerman, B.(2002). Becoming a self-regulated learner: An overview. Theory Into Practice, 41(2), 64-70. 
